Article

\title{
A Label-Free Aptamer-Based Fluorescent Assay for Cadmium Detection
}

\author{
Yunxia Luan ${ }^{1,2}$, Anxiang Lu 1,2,*, Jiayi Chen ${ }^{1,2}$, Hailong Fu ${ }^{1,2}$ and Li Xu ${ }^{1,2}$ \\ 1 Beijing Research Center for Agricultural Standards and Testing, Beijing 100097, China; \\ luanyunxia@163.com (Y.L.); cjy_1666@126.com (J.C.); fuhl@brcast.org.cn (H.F.); xul@brcast.org.cn (L.X.) \\ 2 Beijing Municipal Key Laboratory of Agriculture Environment Monitoring, Beijing 100097, China \\ * Correspondence: luanyx@nercita.org.cn; Tel.: +86-10-5150-3057; Fax: +86-10-5150-3793 \\ Academic Editor: Samuel B. Adeloju \\ Received: 1 November 2016; Accepted: 10 December 2016; Published: 14 December 2016
}

\begin{abstract}
Selective detection of ultratrace amounts of cadmium $\left(\mathrm{Cd}^{2+}\right)$ is extremely important for food safety and environmental monitoring because of its toxicity and widespread use. In this work, we developed a facile, rapid, sensitive, and highly selective method for the detection of $\mathrm{Cd}^{2+}$ based on a label-free aptasensor using an unmodified double-stranded deoxyribonucleic acid-specific dye (PicoGreen). The linear range was $0.10-100 \mu \mathrm{g} / \mathrm{mL}$, and the detection limit $(0.038 \mathrm{ng} / \mathrm{mL})$ was lower than the guideline from the World Health Organization for $\mathrm{Cd}^{2+}$ in drinking water $(3 \mathrm{ng} / \mathrm{mL})$. The sensor exhibited excellent selectivity towards $\mathrm{Cd}^{2+}$ ions. We tested the aptasensor in application to a series of real water samples spiked with different concentrations of $\mathrm{Cd}^{2+}$. Compared with atomic absorption spectrometry, the results showed good tolerance to the matrix effect. The developed approach shows great potential for on-site and high-throughput analysis in routine monitoring.
\end{abstract}

Keywords: aptamer; biosensor; cadmium; PicoGreen; fluorescence

\section{Introduction}

Heavy metal pollution is a very serious environmental problem, and regulations are becoming stricter to address this. To implement action plans for the prevention of water pollution, methods for the detection of pollutants are required. Heavy metals are increasingly problematic in drinking water. Cadmium (Cd) is one of the most toxic elements among the heavy metals, and is widely used in fertilizers, fuels, plastics, toys, and several industrial products [1,2]. Cd tends to accumulate in the kidneys throughout a person's life. According to the Centers for Disease Control and Prevention, Cd ranks seventh out of 275 hazardous substances in the environment [3]. Thus, it is necessary to develop effective, convenient, and inexpensive methods for the detection of $\mathrm{Cd}$.

Many methods have been developed to detect $\mathrm{Cd}$, including inductively coupled plasma mass spectrometry, atomic absorption spectrometry, and electrochemical and fluorescence sensing techniques [4-7]. Among these methods, fluorescence techniques are highly reliable and sensitive for metal ion detection. However, most fluorescence-based $\mathrm{Cd}^{2+}$ sensors are quenched on coordination with large quantities of $\mathrm{Cd}^{2+}$, and they often depend on an irreversible $\mathrm{Cd}^{2+}$-dependent chemical reaction to turn on the fluorescence [8,9]. In addition, these systems use organic solvents, and construction of the methods is generally time consuming and needs complex design. As possible alternatives, aptamers and fluorescent PicoGreen (PG) have attracted attention. Aptamers are single-stranded nucleic acid sequences that are selected via a process known as systematic evolution of ligands by exponential enrichment. They are utilized as molecular recognition elements that can bind various targets with high affinity and specificity [10]. PG is an asymmetric cyanine dye that does not fluoresce when free. On binding to double-stranded deoxyribonucleic acid (dsDNA), it exhibits a more than 1000-fold fluorescence enhancement, but no significant fluorescence change is observed 
when it binds to single stranded DNA [11]. Therefore, an aptamer sensor using PG as the fluorescence enhancement dye might obtain better specificity and detection limit. The aim of the present study was to use aptamers and PG to design a simple, sensitive, and universal fluorescent sensing strategy for $\mathrm{Cd}^{2+}$ detection.

\section{Experimental Section}

\subsection{Reagents and Chemicals}

The oligonucleotide used in this study was obtained from Sangon Biotechnology Co., Ltd. (Shanghai, China), and had the following sequence: $5^{\prime}$-ACCGACCGTGCTGGACTCTGGACTGTTGT GGTATTATTTTTGGTTGTGCAGTATGAGCGAGCGTTGCG-3' [12]. PG $(200 \times$ concentrate) was purchased from Invitrogen (Carlsbad, CA, USA). Other chemicals, including magnesium chloride, Tris- $\mathrm{HCl}$, and phosphate-buffered saline were purchased from the Beijing Chemical Reagent Company (Beijing, China). All solutions were prepared with doubly-distilled water purified by a Milli-Q system (Millipore, Billerica, MA, USA).

\subsection{Instrumentation}

All fluorescence measurements were carried out on a F4500 fluorescence spectrophotometer (Hitachi, Tokyo, Japan) equipped with an aqueous thermostat (Amersham, Stockholm, Sweden) that was accurate to $0.1^{\circ} \mathrm{C}$. The excitation wavelength was set at $480 \mathrm{~nm}$. The excitation and emission slits were set at $5.0 \mathrm{~nm}$ and $10 \mathrm{~nm}$, respectively, with a $700 \mathrm{~V}$ photomultiplier tube voltage. Fluorescence emission spectra were from $500 \mathrm{~nm}$ to $700 \mathrm{~nm}$ with a $0.2 \times 1 \mathrm{~cm}^{2}$ quartz cuvette containing $200 \mu \mathrm{L}$ of the test solution.

\subsection{Fluorescence Detection of $\mathrm{Cd}^{2+}$}

The aptamer $(50 \mu \mathrm{L}, 1 \mu \mathrm{mol} / \mathrm{L})$ was mixed with $100 \mu \mathrm{L}$ of Tris- $\mathrm{HCl}$ buffer (pH 7.4) containing different concentrations $(0 \mathrm{ng} / \mathrm{mL}, 2 \mathrm{ng} / \mathrm{mL}, 20 \mathrm{ng} / \mathrm{mL}, 200 \mathrm{ng} / \mathrm{mL}, 2 \mu \mathrm{g} / \mathrm{mL}, 20 \mu \mathrm{g} / \mathrm{mL}$, or $200 \mu \mathrm{g} / \mathrm{mL}$ ) of $\mathrm{Cd}^{2+}$ in microplate wells. Each solution was incubated at $37^{\circ} \mathrm{C}$ for $15 \mathrm{~min}$. Then, $50 \mu \mathrm{L}$ of the complementary strand of the aptamer $(1 \mu \mathrm{mol} / \mathrm{L})$ and $50 \mu \mathrm{L}$ of $5 \times$ PG were added to the solution. After incubation for another $5 \mathrm{~min}$, the fluorescence intensities were scanned with a fluorescence spectrophotometer with $\lambda_{\mathrm{ex}}$ of $480 \mathrm{~nm}$ and $\lambda_{\mathrm{em}}$ of $530 \mathrm{~nm}$.

\section{Results and Discussion}

\subsection{Working Mechanism}

The detection mechanism of the proposed aptasensor is illustrated in Scheme 1. In the presence of $\mathrm{Cd}^{2+}$, the conformation of the aptamer changes from a random coil structure to an aptamer- $\mathrm{Cd}^{2+}$ complex. After the addition of complementary strands and PG, the complementary strands form a hybrid with the remaining free aptamers that did not bind with $\mathrm{Cd}^{2+}$, which results in a large fluorescent enhancement. Thus, quantitative analysis of $\mathrm{Cd}^{2+}$ can be achieved by monitoring the change in the fluorescence intensity of PG.

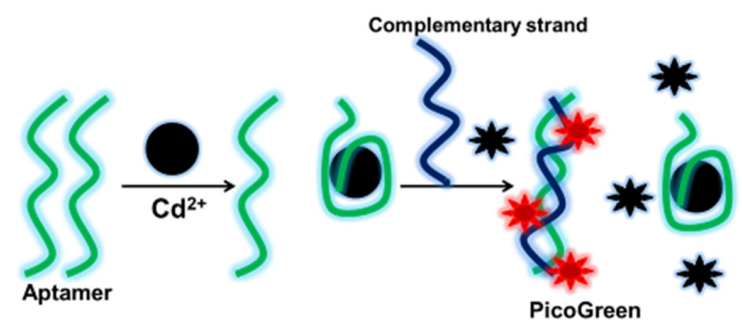

Scheme 1. Fluorescence detection of $\mathrm{Cd}^{2+}$ utilizing PicoGreen as a fluorescent probe. 


\subsection{Optimization of the Experimental Parameters}

To obtain a better signal, it is important to optimize the interaction between PG $(5 \times)$ and dsDNA $(1 \mu \mathrm{mol} / \mathrm{L})$, because of its influence on the fluorescence (Figure 1). With a low concentration of $\mathrm{Cd}^{2+}$ $(1 \mathrm{ng} / \mathrm{mL})$, the fluorescence intensity reached a maximum at $15 \mathrm{~min}$ and then gradually decreased because of decay of the fluorescence of PG. With a higher concentration of $\mathrm{Cd}^{2+}(100 \mu \mathrm{g} / \mathrm{mL})$, the fluorescence intensity peaked at $15 \mathrm{~min}$ and then remained stable. This indicates that there is competition between the aptamer $/ \mathrm{Cd}^{2+}$ complex and aptamer/complementary strand DNA duplex in the first $15 \mathrm{~min}$, and the binding affinity of the aptamer $/ \mathrm{Cd}^{2+}$ complex is stronger than that of the aptamer/complementary strand DNA duplex. Thus, 15 min was selected as an appropriate incubation time in the experiments.

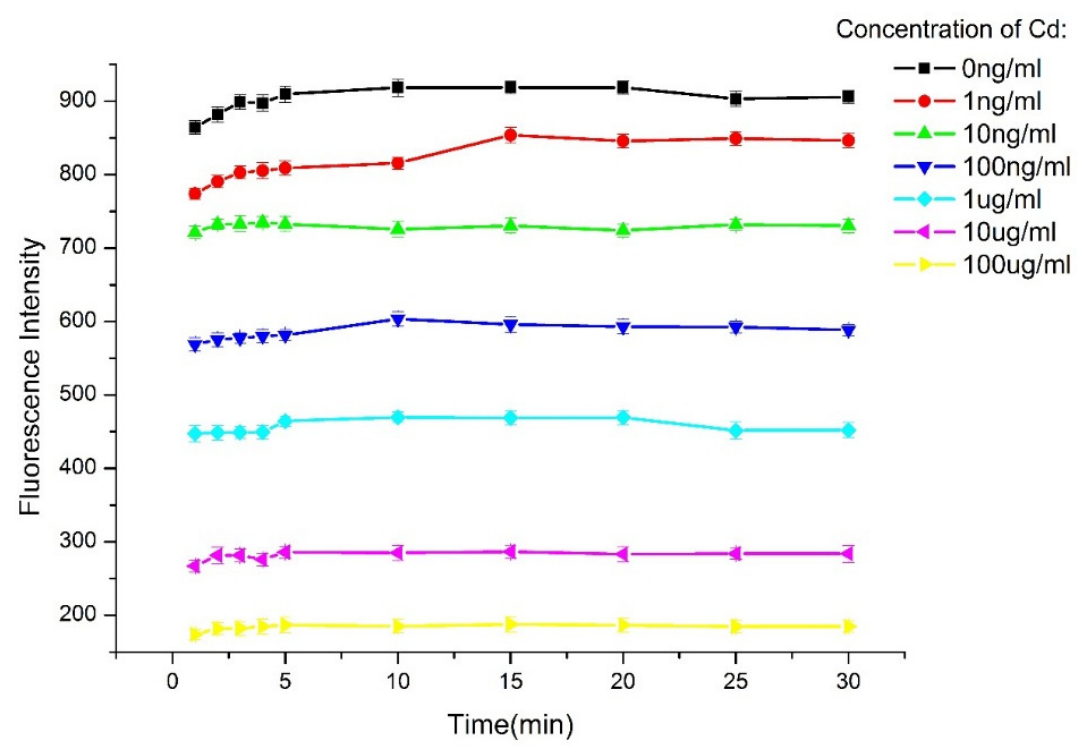

Figure 1. Optimization of the incubation time for the interaction between PicoGreen and double stranded deoxyribonucleic acid at the temperature of $25^{\circ} \mathrm{C}$.

\subsection{Detection Sensitivity}

Fluorescent spectra of solutions with various concentrations of $\mathrm{Cd}^{2+}$ were obtained under optimized conditions (Figure 2A). The fluorescence intensity decreased with increasing $\mathrm{Cd}^{2+}$ concentration. The decrease in the fluorescence signal $\left(F / F_{0}\right)$ was proportional to the logarithm of the $\mathrm{Cd}^{2+}$ concentration over the range $10^{-10}-10^{-4} \mathrm{~g} / \mathrm{mL}$. The values of $F / F_{0}$ and the concentrations of $\mathrm{Cd}^{2+}$ were fitted with the equation $F / F_{0}=-0.36607-0.14278 \mathrm{Lg}\left(\mathrm{C}_{\mathrm{Cd}}\right)$ with a correlation coefficient $\left(R^{2}\right)$ of 0.9929 . The detection limit was estimated as $0.038 \mathrm{ng} / \mathrm{mL}$ using three times the value of the standard deviation (Figure 2B). Compared with other $\mathrm{Cd}^{2+}$ sensors, the aptasensor exhibited higher sensitivity (Table 1). The high sensitivity could be attributed to the formation of the aptamer $/ \mathrm{Cd}^{2+}$ complex, which eliminated competition between the aptamer $/ \mathrm{Cd}^{2+}$ complex and DNA duplex, according to Yan [13]. 


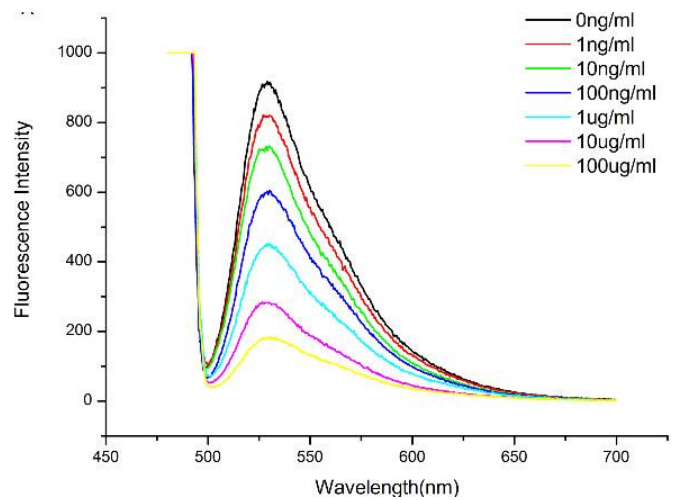

(A)

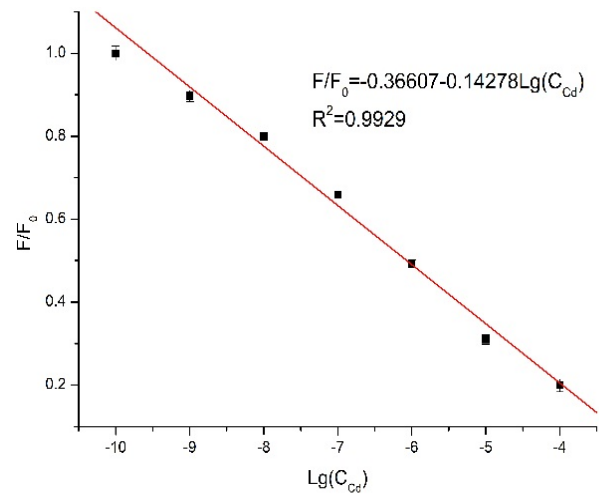

(B)

Figure 2. (A) Fluorescence spectra of solutions with different concentrations of $\mathrm{Cd}^{2+}$; (B) The linearity of $F / F_{0}$ with respect to the logarithmic $\mathrm{Cd}^{2+}$ concentrations.

Table 1. Comparison of different $\mathrm{Cd}^{2+}$ detection methods.

\begin{tabular}{ccccc}
\hline Detection Methods & Detection Limit & Time & Application & Reference \\
\hline FAAS $^{\mathrm{a}}$ & $0.11 \mu \mathrm{g} / \mathrm{L}$ & $>1 \mathrm{~h}$ & Environmental water samples & {$[14]$} \\
GF-AAS $^{\mathrm{b}}$ & $0.006 \mu \mathrm{g} / \mathrm{L}$ & $>1 \mathrm{~h}$ & Beer & {$[15]$} \\
ICP-MS $^{\mathrm{c}}$ & $3 \times 10^{-4} \mu \mathrm{g} / \mathrm{L}$ & $>1 \mathrm{~h}$ & Ocean water & {$[16]$} \\
ICP-AES $^{\mathrm{d}}$ & $0.001 \mu \mathrm{g} / \mathrm{L}$ & $>1 \mathrm{~h}$ & Environmental water samples & {$[17]$} \\
ASV $^{\mathrm{e}}$ & $2.4 \times 10^{-3} \mu \mathrm{g} / \mathrm{L}$ & $30 \mathrm{~min}$ & Vegetables & {$[18]$} \\
HPLC $^{\mathrm{f}}$ & $0.0015 \mu \mathrm{g} / \mathrm{L}$ & $>1 \mathrm{~h}$ & Environmental water samples & {$[19]$} \\
Fluorescence & $0.038 \mu \mathrm{g} / \mathrm{L}$ & $25 \mathrm{~min}$ & Environmental water samples & This work \\
\hline
\end{tabular}

${ }^{a}$ Flameless atomic absorption spectrophotometry; ${ }^{b}$ Graphite furnace atomic absorption spectrometry;

${ }^{\mathrm{c}}$ Inductively coupled plasma mass spectrometry; ${ }^{\mathrm{d}}$ Inductively coupled plasma atomic emission spectrometry;

${ }^{\mathrm{e}}$ Anodic stripping voltammetry; ${ }^{\mathrm{f}}$ High-performance liquid chromatography.

\subsection{Detection Selectivity}

The selectivity of the method was evaluated by monitoring the fluorescence response when the system was challenged with other metal ions $\left(\mathrm{Na}^{+}, \mathrm{Cu}^{2+}, \mathrm{Mg}^{2+}, \mathrm{K}^{+}, \mathrm{As}^{3+}, \mathrm{Ca}^{2+}, \mathrm{Hg}^{2+}, \mathrm{Zn}^{2+}\right.$, and $\left.\mathrm{Pb}^{2+}\right)$ at $0 \mathrm{ng} / \mathrm{mL}, 1 \mathrm{ng} / \mathrm{mL}, 10 \mathrm{ng} / \mathrm{mL}, 1 \mu \mathrm{g} / \mathrm{mL}$, and $1000 \mu \mathrm{g} / \mathrm{mL}$. Compared with background $(0 \mathrm{ng} / \mathrm{mL})$, there was very little change in $F / F_{0}$ on exposure to these metal ions. However, a large decrease in $F / F_{0}$ was induced by $\mathrm{Cd}^{2+}$ (Figure 3). These results show that the method has good selectivity for $\mathrm{Cd}^{2+}$ over other metal ions.

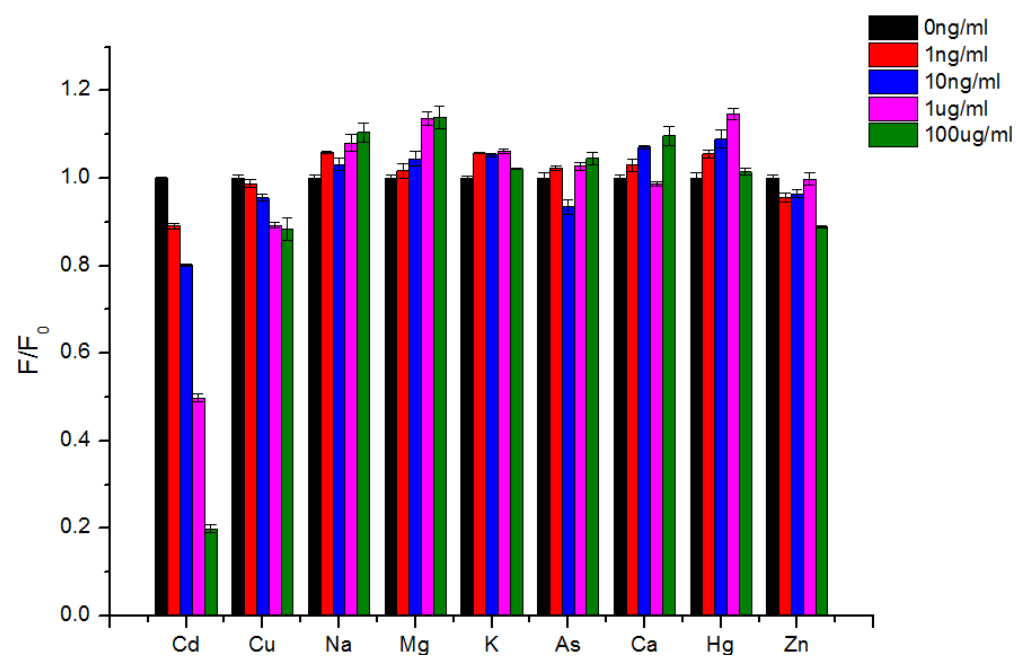

Figure 3. Changes in the relative fluorescence intensity $\left(F / F_{0}\right)$ with various metal ions. 


\subsection{Practical Application}

Finally, the aptasensor was applied to the detection of $\mathrm{Cd}^{2+}$ in lake water collected from Yuyuantan Park in Beijing (Table 2). The lake water was first analyzed by inductively coupled plasma mass spectrometry, and no $\mathrm{Cd}^{2+}$ was detected. After spiking the lake water with $\mathrm{Cd}^{2+}$ at various concentrations $(10,50$, and $100 \mathrm{ng} / \mathrm{mL})$, the samples were analyzed using our fluorescence sensor. The recovery rates were between $89.93 \%$ and $98.1 \%$, demonstrating the excellent performance of this sensor in practical application.

Table 2. $\mathrm{Cd}^{2+}$ concentrations in real lake water samples $(n=3)$.

\begin{tabular}{|c|c|c|c|c|}
\hline Sample & Spiked $\mathrm{Cd}^{2+}\left(\mathrm{ng} \cdot \mathrm{mL}^{-1}\right)$ & $\mathrm{Cd}^{2+}\left(\mathrm{ng} \cdot \mathrm{mL}^{-1}\right)$ & Recovery (\%) & R.S.D. $^{\mathrm{a}}(\%)$ \\
\hline 1 & 100 & 89.93 & 89.93 & 4.11 \\
\hline 2 & 50 & 49.05 & 98.1 & 5.54 \\
\hline 3 & 10 & 9.03 & 90.3 & 4.79 \\
\hline
\end{tabular}

${ }^{a}$ R.S.D.: relative standard deviation.

\section{Conclusions}

Combining an aptamer with PG provides a simple and highly sensitive fluorescent assay for $\mathrm{Cd}^{2+}$ detection. A much lower limit of detection $\left(10^{-10} \mathrm{~g} / \mathrm{mL}\right)$ was obtained. Compared with traditional fluorescence sensors, this system has several unprecedented advantages. First, the fluorescent dye does not need to be attached to DNA, which avoids the tedious process of DNA modification. Second, hybridization of two aptamers enhances the fluorescence generated during the reaction, which improves the detection limit. Third, the versatility of this sensing strategy provides opportunities for the design of new aptasensors for the on-site detection of other pollutants.

Acknowledgments: The authors are grateful to Ai-Liang Chen from the Chinese Academy of Agricultural Sciences. This research was supported by the The National Key Research and Development Program of China (Grant No. 2016YFD0400902) and the National Science Foundation of China (Grant No. 41301350), the Open Project of Beijing Research Center for Agricultural Standards and Testing (Grant No. ATFM-KFKT201601), the Innovation Ability Construction project of the Beijing Academy of Agricultural and Forestry Sciences (Grant No. KJCX20170401).

Author Contributions: Anxiang Lu and Yunxia Luan conceived and designed the experiments; Yunxia Luan, Jiayi Chen performed the experiments; Li Xu and Hailong Fu analyzed the data, and Yunxia Luan wrote the paper.

Conflicts of Interest: The authors declare no conflict of interest.

\section{References}

1. Song, T.; Zhu, X.F.; Zhou, S.H.; Yang, G.; Gan, W.; Yuan, Q.H. DNA derived fluorescent bio-dots for sensitive detection of mercury and silver ions in aqueous solution. Appl. Surf. Sci. 2015, 347, 505-513. [CrossRef]

2. Hua, Z.L.; Yang, B.; Chen, W.; Bai, X.; Xu, Q.J.; Gu, H.X. Surface functionalized magnetic PVA microspheres for rapid naked-eye recognizing of copper (II) ions in aqueous solutions. Appl. Surf. Sci. 2014, 317, $226-235$. [CrossRef]

3. The ATSDR Substance Priority List. Available online: http://www.atsdr.cdc.gov/spl/ (accessed on 7 May 2014).

4. Houk, R.S. Elemental and isotopic analysis by inductively coupled plasma mass spectrometry. Acc. Chem. Res. 1994, 11, 333-339. [CrossRef]

5. Senthilkumar, S.; Saraswathi, R. Electrochemical sensing of cadmium and lead ions at zeolite-modified electrodes: Optimization and field measurements. Sens. Actuators B Chem. 2009, 141, 65-75. [CrossRef]

6. Cheng, T.; Xu, Y.; Zhang, S.; Zhu, W.; Qian, X.; Duan, L. A highly sensitive and selective OFF-ON fluorescent sensor for cadmium in aqueous solution and living cell. J. Am. Chem. Soc. 2008, 48, 16160-16161. [CrossRef] [PubMed]

7. Peng, X.; Du, J.; Fan, J.; Wang, J.; Wu, Y.; Zhao, J.; Sun, S.; Xu, T. A selective fluorescent sensor for imaging $\mathrm{Cd}^{2+}$ in living cells. J. Am. Chem. Soc. 2007, 129, 1500-1501. [CrossRef] [PubMed]

8. Kim, H.N.; Ren, W.X.; Kim, J.S.; Yoon, J. Fluorescent and colorimetric sensors for detection of lead, cadmium, and mercury ions. Chem. Soc. Rev. 2012, 41, 3210-3244. [CrossRef] [PubMed] 
9. Song, H.; Yang, M.; Fan, X.; Wang, H. Turn-on electrochemiluminescence sensing of $\mathrm{Cd}^{2+}$ based on CdTe quantum dots. Spectrochim. Acta A Mol. Biomol. Spectrosc. 2014, 133, 130-133. [CrossRef] [PubMed]

10. Cho, M.; Soo Oh, S.; Nie, J.; Stewart, R.; Eisenstein, M.; Chambers, J.; Marth, J.D.; Walker, F.; Thomson, J.A.; Soh, H.T. Quantitative selection and parallel characterization of aptamers. Proc. Natl. Acad. Sci. USA 2013, 110, 18460-18465. [CrossRef] [PubMed]

11. Dragan, A.I.; Casas-Finet, J.R.; Bishop, E.S.; Strouse, R.J.; Schenerman, M.A.; Geddes, C.D. Characterization of PicoGreen Interaction with dsDNA and the Origin of Its Fluorescence Enhancement upon Binding. Biophys. J. 2010, 99, 3010-3019. [CrossRef] [PubMed]

12. Wu, Y.; Zhan, S.; Wang, L.; Zhou, P. Selection of a DNA aptamer for cadmium detection based on cationic polymer mediated aggregation of gold nanoparticles. Analyst 2014, 139, 1550-1561. [CrossRef] [PubMed]

13. Yan, X.; Cao, Z.; Kai, M.; Lu, J. Label-free aptamer-based chemiluminescence detection of adenosine. Talanta 2009, 79, 383-387. [CrossRef] [PubMed]

14. Zhao, S.L.; Chen, F.S.; Zhang, J.; Ren, S.B.; Liang, H.D.; Li, S.S. On-line flame AAS determination of traces $\mathrm{Cd}(\mathrm{II})$ and $\mathrm{Pb}(\mathrm{II})$ in water samples using thiol-functionalized SBA-15 as solid phase extractant. J. Ind. Eng. Chem. 2015, 27, 362-367. [CrossRef]

15. Borges, S.S.D.; Beinner, M.A.; Silva, J.B.B. Direct Method for Determination of $\mathrm{Al}, \mathrm{Cd}, \mathrm{Cu}$, and $\mathrm{Pb}$ in Beers $\mathrm{In}$ Situ Digested by GF AAS Using Permanent Modifiers. Biol. Trace Elem. Res. 2011, 167, 155-163. [CrossRef] [PubMed]

16. O'Sullivan, J.E.; Watson, R.J.; Butler, E.C. An ICP-MS procedure to determine $\mathrm{Cd}, \mathrm{Co}, \mathrm{Cu}, \mathrm{Ni}, \mathrm{Pb}$ and $\mathrm{Zn}$ in oceanic waters using in line flow injection with solid-phase extraction for preconcentration. Talanta 2013, 115, 999-1010. [CrossRef] [PubMed]

17. Karami, H.; Mousavi, M.F.; Yamini, Y.; Shamsipur, M. On-line preconcentration and simultaneous determination of heavy metal ions by inductively coupled plasma atomic emission spectrometry. Anal. Chim. Acta 2004, 509, 89-94. [CrossRef]

18. Queirolo, F.; Stegen, S.; Restovic, M.; Paz, M.; Ostapczuk, P.; Schwuger, M.J.; Muñoz, L. Total arsenic, lead, and cadmium levels in vegetables cultivated at the Andean villages of northern Chile. Sci. Total Environ. 2000, 255, 75-84. [CrossRef]

19. Xi, T.; Tao, L.H.; Deliang, L.; Qiufen, H.; Guangyu, Y.; Jiayuan, Y. Determination of Heavy Metal Element in Water Samples by Solid Phase Extraction Concentration High Efficiency Liquid Phase Chromatography. Arid Environ. Monit. 2004, 18, 65-68.

(C) 2016 by the authors; licensee MDPI, Basel, Switzerland. This article is an open access article distributed under the terms and conditions of the Creative Commons Attribution (CC-BY) license (http://creativecommons.org/licenses/by/4.0/). 